Article

\title{
Questionnaire on the Training Profile of a Learning Therapy Specialist: Creation and Validation of the Instrument
}

\author{
Laura Martín Martínez and Esther Vela Llauradó *(1) \\ Faculty of Education and Psychology, Francisco de Vitoria University, 28223 Madrid, Spain; 1.martin.prof@ufv.es \\ * Correspondence: esther.vela@ufv.es
}

Received: 25 September 2020; Accepted: 1 November 2020; Published: 3 November 2020

\begin{abstract}
This article provides a description of the creation and validation process for a questionnaire designed to analyze the initial training received by students of degree programs in pre-primary and primary education, specializing in learning therapy. The instrument consists of 175 items in three sections: the first collects sociodemographic data; the second analyzes the initial training received; and the third and final section analyzes the perception of this initial training. The questionnaire was subjected to a double validation process: an evaluation by a panel of experts and a pilot group, these permitted the validation of the content and construct, as well as the corresponding reliability assessment. The results confirm the validity of the questionnaire with an excellent reliability index, allowing the effective evaluation of the training profile of learning therapy specialists.
\end{abstract}

Keywords: initial training; teachers; learning therapy; validation; questionnaire

\section{Introduction}

Special education is a discipline that deals with the education of children with disabilities, addressing their specific needs as have been identified over time [1].

The General Education Act of 1970 saw the first mention of special education and with it a new teacher profile- the learning therapist—responsible for providing the specific educational support necessary in the classroom.

According to article 19 of the Order of 20 August 2010, this professional has multiple responsibilities such as adapting the curriculum to address student needs, developing and adapting materials, providing assistance to teachers, tutoring students with special educational needs and coordinating with mainstream teachers, orientation teams and other professionals who may be involved with these students [2]. They will also work and coordinate with families to ensure effective communication and avoid contradictions that may hinder student learning [3].

All of these functions are designed to improve teaching-learning outcomes, to build student autonomy and active participation in society [4], with the cooperation of all teachers, at all educational levels, in order to develop student potential and meet established objectives [5].

We therefore understand that this is a professional who will engage with a very heterogeneous group with a broad spectrum of needs, both in mainstream and specialized schools. This will require the appropriate training as set forth in the World Report on Disability (2011) [6], which states: "The appropriate training of mainstream teachers is crucial if they are to be confident and competent in teaching children with diverse educational needs. The principles of inclusion should be built into teacher training programs, which should be about attitudes and values not just knowledge and skills" (p. 222). 
This training begins with the initial skills acquired by future teachers during their university studies, with a methodology combining both theory and practice [7]. This combination is important as the goal for university students is to acquire not only theoretical knowledge but also have the appropriate practical skills, attitudes and behaviors to effectively manage the educational challenges they will face professionally [8,9].

As shown by Moriña and Carballo (2018) [10] in their study on the importance of inclusive education, interviewees highlighted the need for useful and practical training that gives teachers the skills to work effectively, to develop curricula, to create materials, etc., that is, specialist teachers able to fulfil their professional responsibilities with confidence, practical knowledge and experience, and devoting the specific attention required by each student with special educational needs to each student.

This conforms to article 4, section I of the Convention on the Rights of Persons with Disabilities (UN, 2006) [11], which highlights the need "to promote the training of professionals and staff working with persons with disabilities in the rights recognised in the present Convention so as to better provide the assistance and services guaranteed by those rights". Furthermore, there are a number of works, including that of González-Gil and Martín (2014) [12], that affirm that the training of professionals is the key to ensuring a quality, inclusive education that attends to the individual needs and characteristics of these students and prepares them for a productive future.

However, we have found that, currently, this professional training is neither unified nor shared across university programs, this is, in part, due to the extinction of the former programs of psycho-pedagogy and special needs education and their substitution with a specialization within the degrees in pre-primary and primary education under the Bologna Process [5]. As shown in a recent article about the analysis of autism spectrum disorder (ASD) classrooms, half of teachers do not feel that they have received the correct initial training for starting their professional activity [13].

Specialization in learning therapy is the training pathway for future teachers of a diverse range of students in the classroom, responsible for the detection and prevention of learning difficulties, employing the necessary strategies for the effective education of students with special needs [14].

There are a number of instruments that evaluate teacher training in educational diversity and inclusion [15], aiming to determine the training received by mainstream teachers in degree programs in pre-primary and primary education in dealing with special needs students. The instruments have resulted in a multitude of studies into the level of teacher training in the area of diversity and inclusion, and the deficiencies encountered in professional practice [16-20]. This is not the case with specialists in learning therapy, as there are no instruments to analyze the support provided to students, teachers and families in order to determine if the training is adequate and suitable to their needs.

Considering that the principal barrier for students with disabilities is the lack of adequate training on the part of teachers, often resulting in negative attitudes towards students with special needs [21-24], it is important to ensure that learning therapy specialists have the appropriate training to work with students and their families, and to provide orientation to mainstream teachers in addressing the needs of students with disabilities. This will help ensure that, based on their initial training, an inclusive education is available to all students [25].

The evaluation of the training of learning therapy specialists, by means of our questionnaire, will help achieve the goal of a quality education for all (goal four) and the reduction of inequalities (goal 10) set out in the United National Agenda 2030 for sustainable development.

Thus, the aim of this research is to create and validate a questionnaire that will allow the effective assessment of the training received by future teachers in degree programs in pre-primary and primary education specializing in learning therapy. Two aspects have been addressed to achieve this objective:

1. Analysis of the content validity and construct of the questionnaire "Profile of the specialist in Learning Therapy"

2. Analysis of the reliability of the questionnaire "Profile of the specialist in Learning Therapy" 


\section{Materials and Methods}

\subsection{Design}

This research applied a descriptive methodology for an objective and verifiable analysis of a specific population. A questionnaire was used to collect information as the easiest and most commonly used tool in the field of education [26].

\subsection{Instrument}

An initial review of existing questions revealed that there are no questionnaires that evaluate the training received by teachers of pre-primary and primary education specializing in learning therapy. Given the diversity of the students with whom they will be working, and the wide range of needs to be addressed, we proceeded to create a questionnaire that asks a series of questions encompassing their knowledge of these needs and how to address them.

The questions were created taking into account the persons to whom they were addressed, aiming to be clear and concise. The questionnaire is of considerable length. This aspect was carefully considered, and it was difficult to reduce the number of items addressing all the aspects deemed necessary for training and intervention.

The questionnaire is structured in three sections. The first deals with sociodemographic data, the second consists of 10 subscales that measure the training profile of the students' information, using a Likert scale from 1 to 5 , where 1 is "I don't know" and 5 is "I know a lot", finally, the third section analyzes their opinions of their initial training, using both open questions and questions using the same Likert scale.

This structure allowed us to make a comprehensive analysis of the specialist teacher by completing the questionnaire in full, or a partial analysis merely using the training subscale.

The initial questionnaire consisted of 186 items. The sections on sociodemographic data and initial training consisted of 15 questions while that on academic training consisted of 171 questions divided into 10 subscales, this structure is illustrated in Table 1 below:

Table 1. Structure of the questionnaire by dimensions, specifications, and number of items.

\begin{tabular}{|c|c|c|c|}
\hline & Dimension & Information & $\mathbf{N}^{\circ}$ Items \\
\hline & Sociodemographic Data & $\begin{array}{l}\text { This section collects the information of the } \\
\text { respondent regarding their qualifications, age, year } \\
\text { of graduation, etc. }\end{array}$ & 8 \\
\hline \multirow{10}{*}{ Training section } & Motor impairment (MI) & \multirow{9}{*}{$\begin{array}{l}\text { For each of the different disabilities or dysfunctions } \\
\text { the theoretical and practical knowledge needed by } \\
\text { teachers is evaluated, as well as their feelings of } \\
\text { competence in dealing with families and their } \\
\text { evaluation of the training they have received in each } \\
\text { of the blocks. }\end{array}$} & 19 \\
\hline & Autism Spectrum Disorder (ASD) & & 17 \\
\hline & Visual impairment (VI) & & 15 \\
\hline & Hearing impairment $(\mathrm{HI})$ & & 15 \\
\hline & Intellectual disability (ID) & & 15 \\
\hline & Personality disorders (PD) & & 18 \\
\hline & Gifted Students (GS) & & 18 \\
\hline & Attention deficit syndrome (ADHD) & & 20 \\
\hline & Specific Learning Disabilities (SLD) & & 13 \\
\hline & Intervention Planning (IPLAN) & $\begin{array}{l}\text { Includes different aspects related to processes and } \\
\text { forms of intervention (Curricular adaptations, } \\
\text { student-centred planning, cooperative learning, etc.) }\end{array}$ & 21 \\
\hline \multicolumn{2}{|r|}{ University training (UTrain) } & $\begin{array}{l}\text { This block evaluates university training in diversity } \\
\text { and inclusion and the specialisation in Learning } \\
\text { Therapy. It includes three open questions to evaluate } \\
\text { the training received at the end of the questionnaire. }\end{array}$ & 7 \\
\hline \multicolumn{2}{|r|}{ TOTAL } & & 186 \\
\hline
\end{tabular}




\subsection{Participants}

Once the questionnaire was created, it was put before a panel of experts. These experts were selected based on the following criteria [27]:

1. Experience in making evaluations.

2. Professional reputation.

3. Availability and willingness to participate.

4. Impartiality and inherent qualities such as confidence and adaptability.

For the expert evaluation, two specialists were selected for each of the disabilities or dysfunctions included in the questionnaire for a total of 18 people. Each of these experts made an evaluation of the block dealing with their area of expertise, providing qualitative analysis of each item, taking into consideration:

1. If the text of each item is clear and correct.

2. If the questions have the appropriate length.

3. If the content of the questions is coherent with each of the blocks.

4. If the response options ( 1 to 5 scale) are appropriate to the questions.

5. Other aspects.

More generally, the experts were also asked to consider if any information or items should be added or eliminated, and any other aspects they wished to comment on.

Furthermore, the questionnaire was posed to a pilot group consisting of 32 recent graduates in pre-primary and primary education specializing in learning therapy, a sample similar to the group we aimed to study. The role of this group was to answer the questionnaire and offer a qualitative analysis, indicating at the end of each block their observations and considerations, the same as the group of experts. They were also asked to evaluate the suitability and length of the questionnaire and the time given for completion.

\subsection{Procedure}

An initial review was conducted of the existing questionnaires used to determine the profile of the learning therapy specialist. It was found that there were no questionnaires that collect the information necessary to effectively evaluate this professional profile.

The next step was the creation of a questionnaire covering the theoretical and practical aspects considered necessary for an effective evaluation of the training received by these specialists.

A group of experts was then consulted to validate the questionnaire, which was subsequently posed to a pilot group to verify that the included items were appropriate. A qualitative evaluation was used in both cases.

Once this information was collected, an analysis was made of the corresponding data.

\subsection{Data Analysis}

The validity of the content and construct was analyzed by means of a panel of experts and a pilot group. A reliability test (Cronbach's alpha) of the complete scale and the various subscales was also conducted.

In all cases, data were analyzed using the SPSS statistical software, version 24.

\section{Results}

The results are presented in two parts. The first part analyzed the validity of the content and construct by means of a panel of experts and a pilot group, the second calculated the homogeneity index of the items and the final reliability test of the complete scale and each of the subscales. 


\subsection{Panel of Experts and Pilot Group}

Based on the evaluation by the panel of experts, the following modifications, additions, or eliminations were made:

a. ASD block—the following items were added:

i. I can create an agenda according to the needs of the ASD students, considering different levels of abstraction.

ii. I can create materials to develop the social skills of ASD students.

b. Visual impairment block—the following item was eliminated as being repetitive:

i. I am familiar with Braille print.

c. Hearing impairment block-dactylology and fingerspelling were specified in the item referring to deaf-blindness.

d. Personality disorders block - three items referring to the classification of dysfunctions in the DSM-V in A, B and C were eliminated as irrelevant from an educational point of view, but the specific needs produced by these dysfunctions are relevant.

Based on the opinions of the panel of experts, the indicated items were added or removed (Table 2). The initial questionnaire consisted of 186 items, later reduced to 184 items: eight in the sociodemographic section and 176 in the training section after the modification of items related to "Autism Spectrum Disorder", "Visual impairment", "Hearing impairment" and "Personality disorders".

Table 2. Final distribution of items by the dimensions of the questionnaire.

\begin{tabular}{cccccc}
\hline Dimension & $\begin{array}{c}\mathbf{N}^{\mathbf{o}} \text { Items } \\
\text { Initially }\end{array}$ & $\begin{array}{c}\mathbf{N}^{\mathbf{2}} \text { Items } \\
\text { Eliminated }\end{array}$ & $\begin{array}{c}\mathbf{N}^{\mathbf{o}} \text { Items } \\
\text { Added }\end{array}$ & $\begin{array}{c}\mathbf{N}^{\mathbf{o}} \text { Items } \\
\text { Modified }\end{array}$ & $\begin{array}{c}\mathbf{N}^{\mathbf{0}} \text { Items } \\
\text { Final }\end{array}$ \\
\hline Sociodemographic data & 8 & 0 & 0 & 0 & 8 \\
Motor impairment (MI) & 19 & 0 & 0 & 0 & 19 \\
Autism Spectrum Disorder (ASD) & 17 & 0 & 2 & 0 & 19 \\
Visual impairment (VI) & 15 & 1 & 0 & 0 & 14 \\
Hearing impairment (HI) & 15 & 0 & 0 & 1 & 15 \\
Intellectual disability (ID) & 15 & 0 & 0 & 0 & 15 \\
Personality disorders (PD) & 18 & 3 & 0 & 0 & 15 \\
Gifted Students (GS) & 18 & 0 & 0 & 0 & 18 \\
Attention Deficit Hyperactivity & 20 & 0 & 0 & 0 & 20 \\
Syndrome (ADHD) & 13 & 0 & 0 & 0 & 13 \\
Specific Learning Disabilities (SLD) & 21 & 0 & 0 & 0 & 21 \\
Intervention Planning (IPLAN) & 7 & 0 & 0 & 0 & 7 \\
University training & 186 & 4 & 2 & 1 & 184 \\
\hline TOTAL & & & & & \\
\hline
\end{tabular}

The pilot group did not suggest any changes, considering the items to be appropriate, except with regard to the length of the questionnaire. It was decided not to make changes in the length given the importance of the information evaluated.

\subsection{Reliability Assessment}

The questionnaire was administered to a pilot group of 32 students in order to determine their comprehension of the items and analyze the construct validity.

To analyze the construct validity, a homogeneity test was conducted of the items of each subscale to eliminate those with low discrimination $(<20)$ or those with a low correlation but above 20, and thus increase the reliability of the instrument if eliminated. A reliability test was also conducted using Cronbach's alpha, before and after eliminating the items with low correlation to verify the difference. 
Table 3 shows the results of these tests, showing how the elimination of a number of items enhanced the reliability of the scale, not the instrument as a whole in the training section. The reliability index of the instrument is good or excellent in all scales according to the criteria of George and Mallery (2003, p. 231) [28].

Table 3. Analysis of the homogeneity and reliability of the items.

\begin{tabular}{|c|c|c|c|c|c|}
\hline Subscale & Items & $\begin{array}{c}\text { Eliminated Items } \\
\text { (Discrimination Index) }\end{array}$ & $\mathbf{N}^{o}$ Items Final & $\begin{array}{c}\text { Initial Cronbach's } \\
\text { Alpha }\end{array}$ & $\begin{array}{c}\text { Final Cronbach's } \\
\text { Alpha }\end{array}$ \\
\hline MI & $1-19$ & $\begin{array}{l}\text { Item } 16(0.288) \\
\text { Item } 19(0.232)\end{array}$ & 17 & 0.898 & 0.911 \\
\hline ASD & $20-38$ & $\begin{array}{l}\text { Item } 35(0.234) \\
\text { Item } 38(0.329)\end{array}$ & 17 & 0.945 & 0.962 \\
\hline VI & $39-52$ & Item 43 (0.293) & 13 & 0.863 & 0.866 \\
\hline $\mathrm{HI}$ & $53-67$ & $\begin{array}{l}\text { Item } 61(0.300) \\
\text { Item } 64(0.377)\end{array}$ & 13 & 0.906 & 0.915 \\
\hline ID & $68-82$ & - & 15 & 0.924 & 0.924 \\
\hline PD & $83-97$ & - & 15 & 0.974 & 0.974 \\
\hline GS & 98-115 & Item $101(0.442)$ & 17 & 0.950 & 0.953 \\
\hline ADHD & $116-135$ & - & 20 & 0.948 & 0.948 \\
\hline SLD & $136-148$ & - & 13 & 0.870 & 0.870 \\
\hline IPLAN & 149-169 & Item $150(0.111)$ & 20 & 0.918 & 0.925 \\
\hline Total & 169 & & 160 & 0.986 & 0.986 \\
\hline
\end{tabular}

Note: MI: motor impairment; ASD: autism spectrum disorder; VI: visual impairment; HI: hearing impairment; ID: intellectual disability; PD: personality disorders; GS: gifted students; ADHD: attention deficit hyperactivity disorder; SLD: specific learning disabilities; IPLAN: intervention planning.

After the validation of the content and the construct, the final questionnaire had a total of 175 items, of which, 160 corresponded to the training section, configured into different subscales. The final questionnaire is provided in Appendix A.

\section{Discussion and Conclusions}

This work describes the process of validation of a questionnaire created to analyze the training profile of learning therapy specialists. A number of studies provide a general assessment of the university training of mainstream teachers [29-32] and for more specific teacher profiles such as specialists in physical education [33], music [34] or foreign languages [35]. However, when we looked at specialists in learning therapy, we found that many studies analyze more general aspects of pre-primary and primary teacher training in the area of educational diversity and inclusion, making use of instruments designed for this type of analysis [14], but not for the profile of the learning therapy specialist. Thus, the present work aims to validate an instrument that will allow the analysis of the training in this professional field.

This section offers some of the principal conclusions drawn from the results of the analysis of the design and psychometric properties of the questionnaire.

Firstly, we assessed the content and construct validity using a panel of experts of an appropriate number according to previous studies [36-38]. These experts performed a qualitative analysis to determine the suitability of both the questionnaire as a whole and each of the items. Certain minor changes were made to improve the questionnaire.

The questionnaire was subsequently analyzed for homogeneity, eliminating those items with low correlations and therefore enhancing the reliability of the subscales. We determined that the reliability was excellent in general terms and good to excellent in the different subscales.

The work has allowed us to develop an important instrument for evaluating the training profile of the learning therapy specialist, a professional who must address the highly diverse needs of a highly 
diverse set of students. To do this effectively, it is essential that these professionals have the appropriate training. The assessment of learning therapists will reveal the current reality in order to identify areas for improvement, starting with initial professional training, with clear and objective criteria.

However, there are certain limitations to the present study that should be noted. Firstly, the questionnaire may be too long, a possible impediment to those who need to complete it. Secondly, the size of the pilot group was limited and should be expanded in order to have a more substantial and generalizable data set.

Author Contributions: L.M.M. and E.V.L. worked jointly on the data processing and on the composition of the paper. All authors have read and agreed to the published version of the manuscript.

Funding: This research received no external funding.

Conflicts of Interest: The authors declare no conflict of interest.

\section{Appendix A}

Questionnaire on the training profile-learning therapy specialists

Sociodemographic data:

\section{Qualification:}

$\square$ Degree in pre-primary education.

$\square$ Degree in primary education

\section{Specialization: \\ $\square$ Learning therapy \\ $\square$ Other \\ University where you studied .

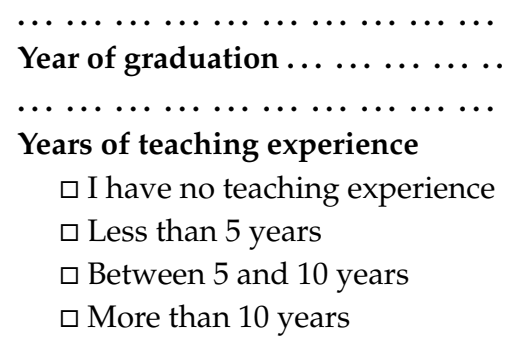

\section{Are you currently working? \\ $\square$ Yes \\ $\square$ No}

If the answer is Yes:

$\square$ You are a mainstream classroom teacher

$\begin{aligned} & \square \text { Pre-primary } \\ & \square \text { Primary } \\ & \square \text { Secondary } \\ & \square \text { Pre-primary } \\ & \square \text { Primary } \\ & \square \text { Secondary }\end{aligned}$

Age $\ldots \ldots \ldots \ldots \ldots \ldots \ldots \ldots$

\section{Gender}

$$
\begin{aligned}
& \square \text { Male } \\
& \square \text { Female }
\end{aligned}
$$


Training analysis:

Table A1. Motor impairment (MI).

\begin{tabular}{|c|c|c|c|c|c|c|c|}
\hline $\mathbf{N}^{\mathbf{o}}$ & ITEM & Not at All & Very Little & Slightly & Somewhat & A Great Deal & Totally \\
\hline 1 & I am familiar with the needs of students with MI. & 1 & 2 & 3 & 4 & 5 & 6 \\
\hline 2 & $\begin{array}{c}\text { I am able to address the needs of students with MI in the LT } \\
\text { classroom. }\end{array}$ & 1 & 2 & 3 & 4 & 5 & 6 \\
\hline 3 & $\begin{array}{l}\text { I am able to address the needs of students with MI in the } \\
\text { mainstream classroom. }\end{array}$ & 1 & 2 & 3 & 4 & 5 & 6 \\
\hline 4 & $\begin{array}{l}\text { I am able to create education materials adapted to the needs of } \\
\text { students with MI. }\end{array}$ & 1 & 2 & 3 & 4 & 5 & 6 \\
\hline 5 & $\begin{array}{l}\text { I am familiar with alternative and augmentative communication } \\
\text { systems. }\end{array}$ & 1 & 2 & 3 & 4 & 5 & 6 \\
\hline 6 & I am familiar with pictograms are. & 1 & 2 & 3 & 4 & 5 & 6 \\
\hline 7 & I am familiar with a communication board is. & 1 & 2 & 3 & 4 & 5 & 6 \\
\hline 8 & $\begin{array}{l}\text { I am able to create a communication board (using BLISS, SPC, } \\
\text { ARASAAC). }\end{array}$ & 1 & 2 & 3 & 4 & 5 & 6 \\
\hline 9 & I am familiar with an E-TRAN board is. & 1 & 2 & 3 & 4 & 5 & 6 \\
\hline 10 & $\begin{array}{l}\text { I know of ICT programs and tools that facilitate access to } \\
\text { communication. }\end{array}$ & 1 & 2 & 3 & 4 & 5 & 6 \\
\hline 11 & I am familiar with support technologies. & 1 & 2 & 3 & 4 & 5 & 6 \\
\hline 12 & $\begin{array}{l}\text { I am able to introduce support technologies to facilitate learning } \\
\text { for students with MI in the classroom. }\end{array}$ & 1 & 2 & 3 & 4 & 5 & 6 \\
\hline 13 & I am familiar with basal stimulation is. & 1 & 2 & 3 & 4 & 5 & 6 \\
\hline 14 & I am familiar with multisensorial stimulation is. & 1 & 2 & 3 & 4 & 5 & 6 \\
\hline 15 & I am able to create sensorial materials for the classroom. & 1 & 2 & 3 & 4 & 5 & 6 \\
\hline 16 & $\begin{array}{l}\text { I believe my current level of training in motor impairment allows } \\
\text { me to provide basic orientation to families. }\end{array}$ & 1 & 2 & 3 & 4 & 5 & 6 \\
\hline 17 & $\begin{array}{l}\text { I believe my current level of training is adequate to address the } \\
\text { needs of students with MI. }\end{array}$ & 1 & 2 & 3 & 4 & 5 & 6 \\
\hline
\end{tabular}


Table A2. Autism spectrum disorder (ASD).

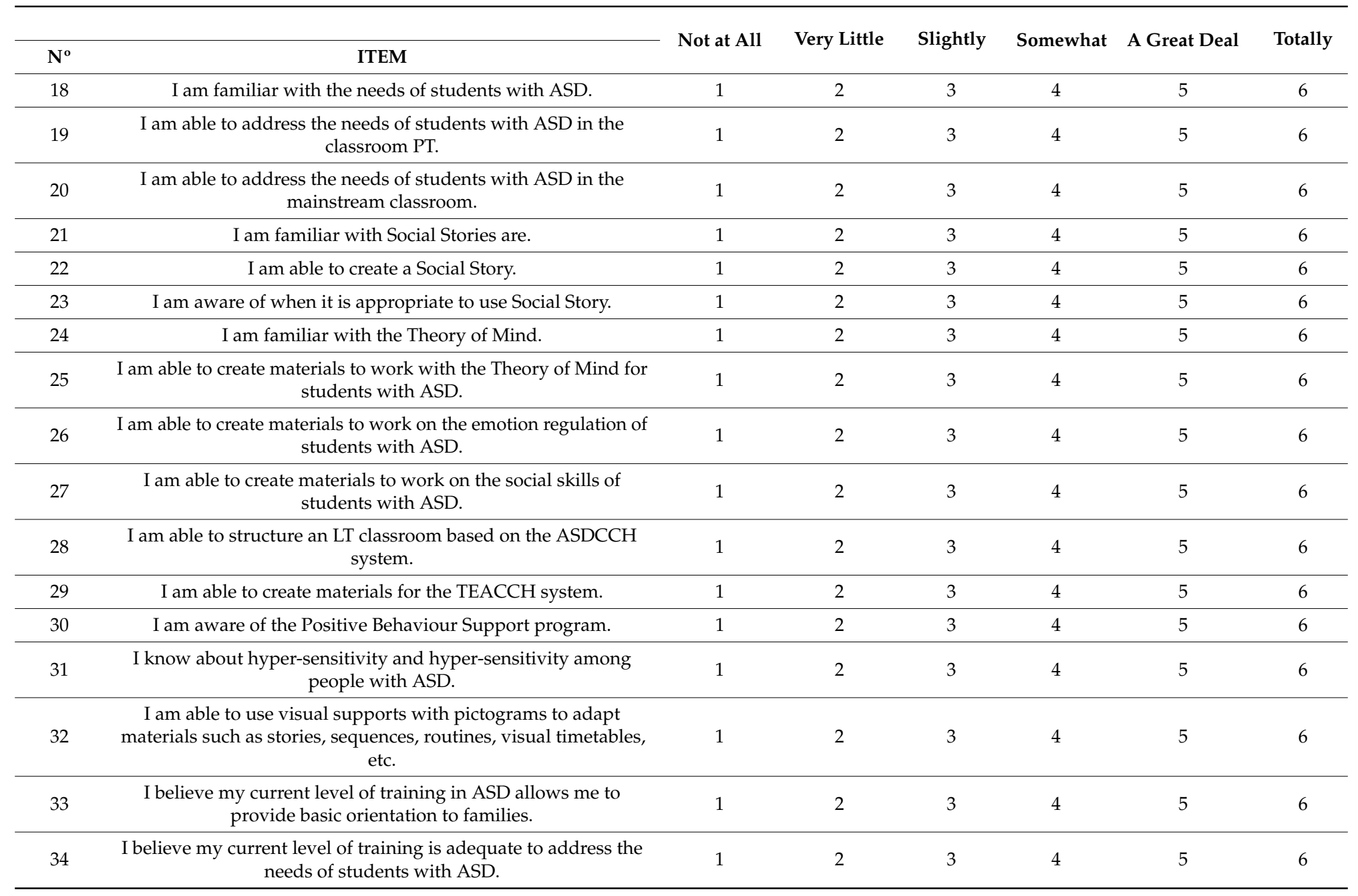

Sensory disabilities: 
Table A3. Visual impairment (VI)

\begin{tabular}{|c|c|c|c|c|c|c|c|}
\hline $\mathbf{N}^{\circ}$ & ITEM & Not at All & Very Little & Slightly & Somewhat & A Great Deal & Totally \\
\hline 35 & I am familiar with the needs of students with visual impairment. & 1 & 2 & 3 & 4 & 5 & 6 \\
\hline 36 & $\begin{array}{l}\text { I know how to address the needs of students with visual } \\
\text { impairment in the LT classroom. }\end{array}$ & 1 & 2 & 3 & 4 & 5 & 6 \\
\hline 37 & $\begin{array}{l}\text { I know how to address the needs of students with visual } \\
\text { impairment in the mainstream classroom. }\end{array}$ & 1 & 2 & 3 & 4 & 5 & 6 \\
\hline 38 & I am familiar with Tiflotechnology. & 1 & 2 & 3 & 4 & 5 & 6 \\
\hline 39 & I am able to create a text in Braille. & 1 & 2 & 3 & 4 & 5 & 6 \\
\hline 40 & I am familiar with the Braille Terminal. & 1 & 2 & 3 & 4 & 5 & 6 \\
\hline 41 & I am familiar with the Perkins Brailler. & 1 & 2 & 3 & 4 & 5 & 6 \\
\hline 42 & $\begin{array}{c}\text { I am able to address the spatial-temporal needs of students with } \\
\text { visual impairment. }\end{array}$ & 1 & 2 & 3 & 4 & 5 & 6 \\
\hline 43 & $\begin{array}{l}\text { I am able to create supports as a guide for the spatial-temporal } \\
\text { needs of students with deaf-blindness. }\end{array}$ & 1 & 2 & 3 & 4 & 5 & 6 \\
\hline 44 & $\begin{array}{l}\text { I am able to adapt materials for students with visual impairment } \\
\text { (i.e., text in high relief). }\end{array}$ & 1 & 2 & 3 & 4 & 5 & 6 \\
\hline 45 & $\begin{array}{l}\text { I believe my current level of training in visual impairment allows } \\
\text { me to provide basic orientation to families. }\end{array}$ & 1 & 2 & 3 & 4 & 5 & 6 \\
\hline 46 & $\begin{array}{l}\text { I believe my current level of training is adequate to address the } \\
\text { needs of students with visual impairment. }\end{array}$ & 1 & 2 & 3 & 4 & 5 & 6 \\
\hline 47 & $\begin{array}{l}\text { I believe the training received in university is adequate to } \\
\text { address the needs of students with visual impairment. }\end{array}$ & 1 & 2 & 3 & 4 & 5 & 6 \\
\hline
\end{tabular}


Table A4. Hearing impairment (HI).

\begin{tabular}{|c|c|c|c|c|c|c|c|}
\hline $\mathbf{N}^{\circ}$ & ITEM & Not at All & Very Little & Slightly & Somewhat & A Great Deal & Totally \\
\hline 48 & $\begin{array}{c}\text { I am familiar with the needs of students with hearing } \\
\text { impairment. }\end{array}$ & 1 & 2 & 3 & 4 & 5 & 6 \\
\hline 49 & $\begin{array}{l}\text { I know how to address the needs of students with hearing } \\
\text { impairment in the LT classroom. }\end{array}$ & 1 & 2 & 3 & 4 & 5 & 6 \\
\hline 50 & $\begin{array}{l}\text { I know how to address the needs of students with hearing } \\
\text { impairment in the mainstream classroom. }\end{array}$ & 1 & 2 & 3 & 4 & 5 & 6 \\
\hline 51 & I am familiar with the FM System is for hearing impairment. & 1 & 2 & 3 & 4 & 5 & 6 \\
\hline 52 & I am familiar with cued speech is. & 1 & 2 & 3 & 4 & 5 & 6 \\
\hline 53 & I am familiar with the bimodal communication system. & 1 & 2 & 3 & 4 & 5 & 6 \\
\hline 54 & I am able to communicate in signs using the bimodal structure. & 1 & 2 & 3 & 4 & 5 & 6 \\
\hline 55 & I am familiar with Sign Language. & 1 & 2 & 3 & 4 & 5 & 6 \\
\hline 56 & I am familiar with dactylology or fingerspelling. & 1 & 2 & 3 & 4 & 5 & 6 \\
\hline 57 & I am able to communicate using dactylology. & 1 & 2 & 3 & 4 & 5 & 6 \\
\hline 58 & $\begin{array}{l}\text { I believe my current level of training in hearing impairment } \\
\text { allows me to provide basic orientation to families. }\end{array}$ & 1 & 2 & 3 & 4 & 5 & 6 \\
\hline 59 & $\begin{array}{l}\text { I believe my current level of training is adequate to address the } \\
\text { needs of students with hearing impairment. }\end{array}$ & 1 & 2 & 3 & 4 & 5 & 6 \\
\hline 60 & $\begin{array}{l}\text { I believe the training received in university is adequate to } \\
\text { address the needs of students with hearing impairment. }\end{array}$ & 1 & 2 & 3 & 4 & 5 & 6 \\
\hline
\end{tabular}


Table A5. Intellectual disability (ID).

\begin{tabular}{|c|c|c|c|c|c|c|c|}
\hline $\mathbf{N}^{\mathbf{o}}$ & ITEM & Not at All & Very Little & Slightly & Somewhat & A Great Deal & Totally \\
\hline 61 & I am familiar with the needs of students with ID. & 1 & 2 & 3 & 4 & 5 & 6 \\
\hline 62 & $\begin{array}{c}\text { I know how to address the needs of students with ID in the LT } \\
\text { classroom. }\end{array}$ & 1 & 2 & 3 & 4 & 5 & 6 \\
\hline 63 & $\begin{array}{l}\text { I know how to address the needs of students with ID in the } \\
\text { mainstream classroom. }\end{array}$ & 1 & 2 & 3 & 4 & 5 & 6 \\
\hline 64 & $\begin{array}{c}\text { I am aware of the priority areas in addressing the needs of } \\
\text { students with ID. }\end{array}$ & 1 & 2 & 3 & 4 & 5 & 6 \\
\hline 65 & I am familiar with individual support plans. & 1 & 2 & 3 & 4 & 5 & 6 \\
\hline 66 & I am able to create an individual support plan. & 1 & 2 & 3 & 4 & 5 & 6 \\
\hline 67 & $\begin{array}{l}\text { I am aware of the different intensities of support for students } \\
\text { with ID. }\end{array}$ & 1 & 2 & 3 & 4 & 5 & 6 \\
\hline 68 & $\begin{array}{l}\text { I am familiar with the five basic dimensions in the assessment of } \\
\text { intellectual disability. }\end{array}$ & 1 & 2 & 3 & 4 & 5 & 6 \\
\hline 69 & $\begin{array}{l}\text { I am familiar with the four steps in the planning and evaluation } \\
\text { of the support required by students with ID. }\end{array}$ & 1 & 2 & 3 & 4 & 5 & 6 \\
\hline 70 & I am familiar with co-active, cooperative and reactive learning. & 1 & 2 & 3 & 4 & 5 & 6 \\
\hline 71 & $\begin{array}{l}\text { I am familiar with the principal behavioural problems associated } \\
\text { with ID. }\end{array}$ & 1 & 2 & 3 & 4 & 5 & 6 \\
\hline 72 & I am able to create a behaviour modification program. & 1 & 2 & 3 & 4 & 5 & 6 \\
\hline 73 & $\begin{array}{l}\text { I believe my current level of training in intellectual disability } \\
\text { allows me to provide basic orientation to families. }\end{array}$ & 1 & 2 & 3 & 4 & 5 & 6 \\
\hline 74 & $\begin{array}{l}\text { I believe my current level of training is adequate to address the } \\
\text { needs of students with ID. }\end{array}$ & 1 & 2 & 3 & 4 & 5 & 6 \\
\hline 75 & $\begin{array}{l}\text { I believe the training received in university is adequate to } \\
\text { address the needs of students with ID. }\end{array}$ & 1 & 2 & 3 & 4 & 5 & 6 \\
\hline
\end{tabular}


Table A6. Personality disorder (PD).

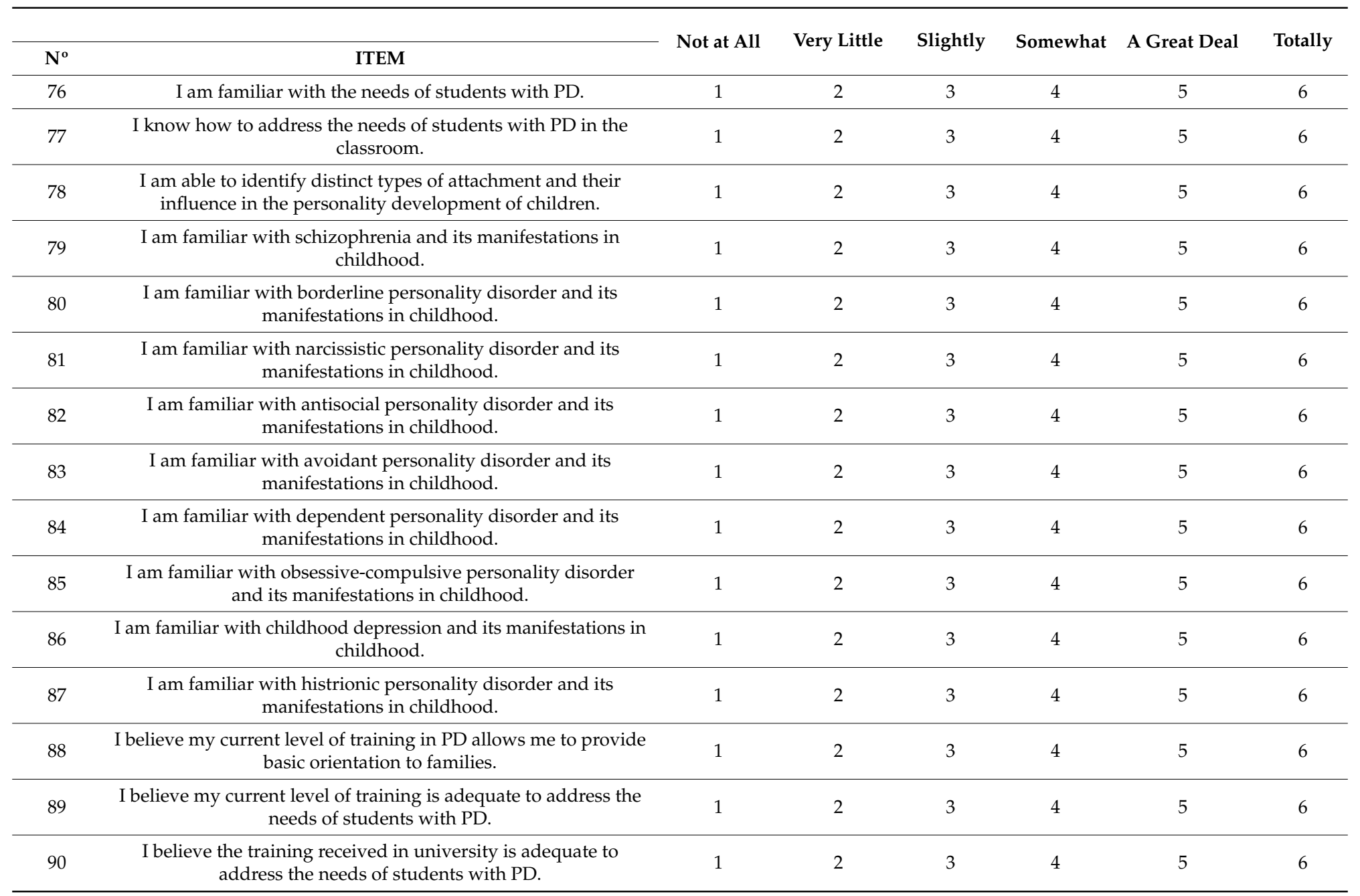


Table A7. Gifted students (GS).

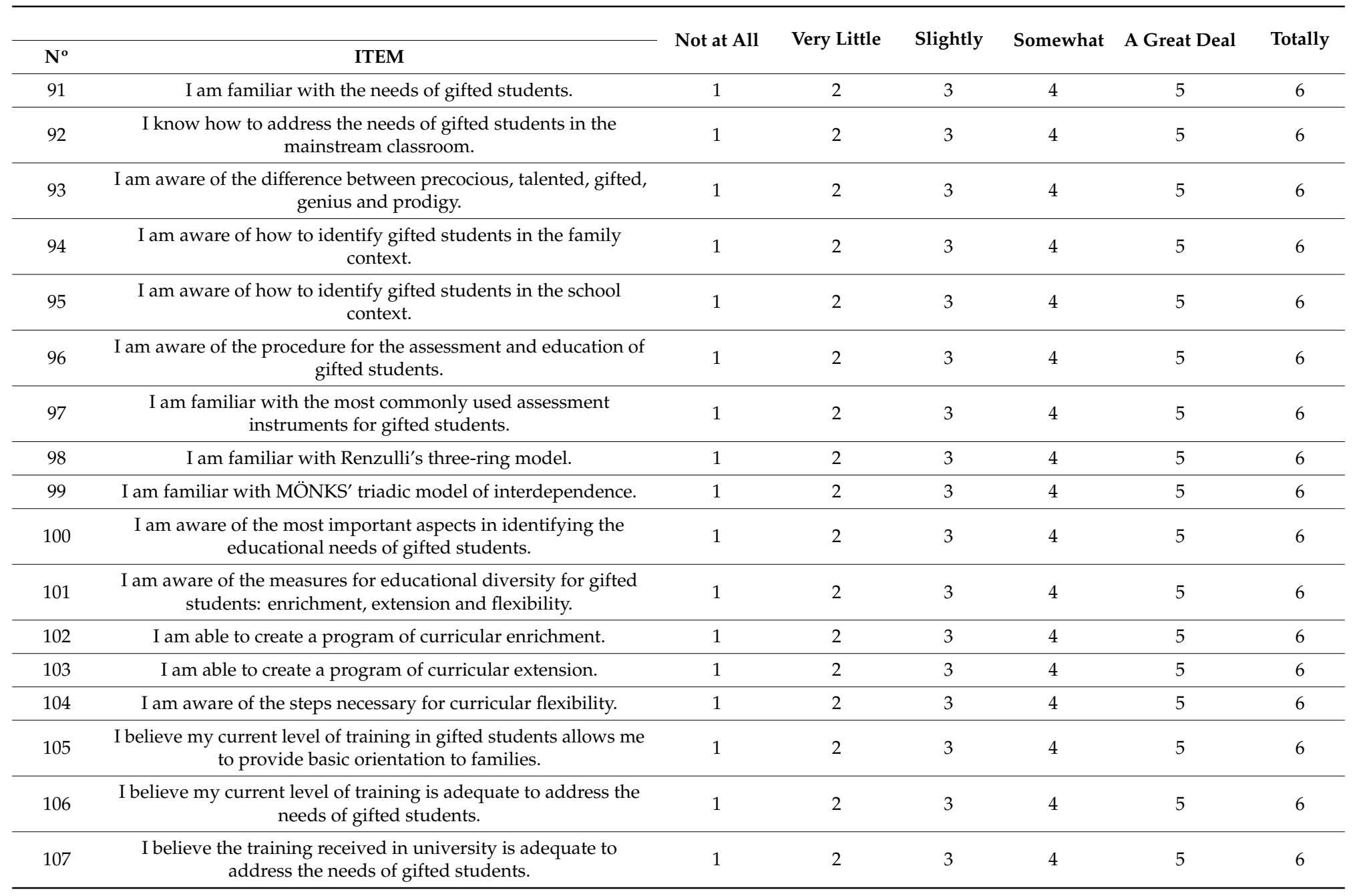


Table A8. Attention deficit hyperactivity disorder (ADHD).

\begin{tabular}{|c|c|c|c|c|c|c|c|}
\hline $\mathbf{N}^{\circ}$ & ITEM & Not at All & Very Little & Slightly & Somewhat & A Great Deal & Totally \\
\hline 108 & I am familiar with the needs of students with ADHD. & 1 & 2 & 3 & 4 & 5 & 6 \\
\hline 109 & $\begin{array}{l}\text { I know how to address the needs of students with ADHD in the } \\
\text { LT classroom. }\end{array}$ & 1 & 2 & 3 & 4 & 5 & 6 \\
\hline 110 & $\begin{array}{l}\text { I know how to address the needs of students with ADHD in the } \\
\text { mainstream classroom. }\end{array}$ & 1 & 2 & 3 & 4 & 5 & 6 \\
\hline 112 & I am familiar with executive functions. & 1 & 2 & 3 & 4 & 5 & 6 \\
\hline 113 & I am able to plan an intervention to develop executive functions. & 1 & 2 & 3 & 4 & 5 & 6 \\
\hline 114 & I am familiar with the comorbidities of ADHD. & 1 & 2 & 3 & 4 & 5 & 6 \\
\hline 115 & I am aware of cognitive therapy. & 1 & 2 & 3 & 4 & 5 & 6 \\
\hline 116 & I am able to plan activities based on cognitive therapy. & 1 & 2 & 3 & 4 & 5 & 6 \\
\hline 120 & I am aware of the learning difficulties of students with ADHD. & 1 & 2 & 3 & 4 & 5 & 6 \\
\hline 121 & $\begin{array}{l}\text { I am able to address the reading, writing and mathematics needs } \\
\text { of students with ADHD. }\end{array}$ & 1 & 2 & 3 & 4 & 5 & 6 \\
\hline 122 & I am familiar with mental operation and their relation to ADHD. & 1 & 2 & 3 & 4 & 5 & 6 \\
\hline 123 & $\begin{array}{c}\text { I am able to plan assignments for students with ADHD based on } \\
\text { thought routines. }\end{array}$ & 1 & 2 & 3 & 4 & 5 & 6 \\
\hline 124 & $\begin{array}{l}\text { I am able to plan assignments for students with ADHD based on } \\
\text { graphic organisers. }\end{array}$ & 1 & 2 & 3 & 4 & 5 & 6 \\
\hline 125 & $\begin{array}{l}\text { I believe my current level of training in ADHD allows me to } \\
\text { provide basic orientation to families. }\end{array}$ & 1 & 2 & 3 & 4 & 5 & 6 \\
\hline 126 & $\begin{array}{l}\text { I believe my current level of training is adequate to address the } \\
\text { needs of students with ADHD. }\end{array}$ & 1 & 2 & 3 & 4 & 5 & 6 \\
\hline
\end{tabular}


Table A9. Specific learning disabilities (SLD).

\begin{tabular}{|c|c|c|c|c|c|c|c|}
\hline $\mathbf{N}^{\circ}$ & ITEM & Not at All & Very Little & Slightly & Somewhat & A Great Deal & Totally \\
\hline 128 & I am familiar with the needs of students with SLD & 1 & 2 & 3 & 4 & 5 & 6 \\
\hline 129 & $\begin{array}{c}\text { I know how to address the needs of students with SLD in the } \\
\text { classroom. }\end{array}$ & 1 & 2 & 3 & 4 & 5 & 6 \\
\hline 130 & $\begin{array}{l}\text { I am aware of the principal reading difficulties (dyslexia) of } \\
\text { students with SLD. }\end{array}$ & 1 & 2 & 3 & 4 & 5 & 6 \\
\hline 131 & $\begin{array}{l}\text { I am able to address the principal reading difficulties of students } \\
\text { with SLD. }\end{array}$ & 1 & 2 & 3 & 4 & 5 & 6 \\
\hline 132 & $\begin{array}{l}\text { I am aware of the principal difficulties in writing (dysgraphia) of } \\
\text { students with SLD. }\end{array}$ & 1 & 2 & 3 & 4 & 5 & 6 \\
\hline 133 & $\begin{array}{l}\text { I am able to address the principal writing difficulties of students } \\
\text { with SLD. }\end{array}$ & 1 & 2 & 3 & 4 & 5 & 6 \\
\hline 134 & $\begin{array}{l}\text { I am aware of the principal difficulties in mathematics } \\
\text { (dyscalculia) of students specific learning disabilities. }\end{array}$ & 1 & 2 & 3 & 4 & 5 & 6 \\
\hline 135 & $\begin{array}{l}\text { I am able to address the principal difficulties in mathematics of } \\
\text { students with specific learning disabilities. }\end{array}$ & 1 & 2 & 3 & 4 & 5 & 6 \\
\hline 136 & I am familiar with Non-verbal Learning Disorder (NVLD) & 1 & 2 & 3 & 4 & 5 & 6 \\
\hline 137 & $\begin{array}{l}\text { I am able to address the principal difficulties of students with } \\
\text { NVLD. }\end{array}$ & 1 & 2 & 3 & 4 & 5 & 6 \\
\hline 138 & $\begin{array}{l}\text { I believe my current level of training in specific learning } \\
\text { disabilities allows me to provide basic orientation to families. }\end{array}$ & 1 & 2 & 3 & 4 & 5 & 6 \\
\hline 139 & $\begin{array}{l}\text { I believe my current level of training is adequate to address the } \\
\text { needs of students with SLD. }\end{array}$ & 1 & 2 & 3 & 4 & 5 & 6 \\
\hline 140 & $\begin{array}{l}\text { I believe the training received in university is adequate to } \\
\text { address the needs of students with SLD. }\end{array}$ & 1 & 2 & 3 & 4 & 5 & 6 \\
\hline
\end{tabular}


Table A10. Intervention planning.

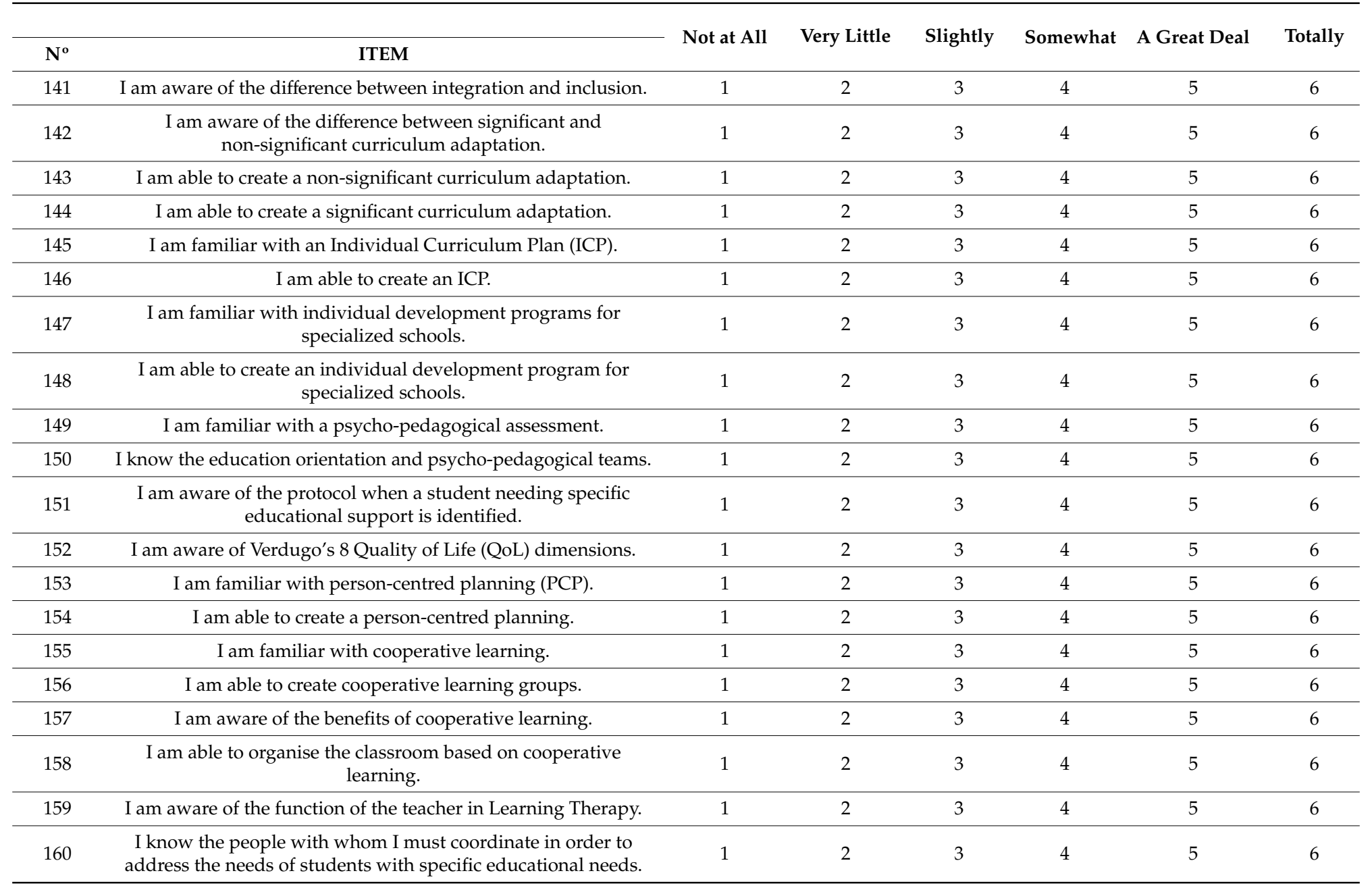


Table A11. University training

\begin{tabular}{|c|c|c|c|c|c|c|}
\hline ITEM & Not at All & Very Little & Slightly & Somewhat & A Great Deal & Totally \\
\hline I have received training in learning diversity in university. & 1 & 2 & 3 & 4 & 5 & 6 \\
\hline $\begin{array}{l}\text { I believe my current level of training in diversity is } \\
\text { adequate. }\end{array}$ & 1 & 2 & 3 & 4 & 5 & 6 \\
\hline $\begin{array}{l}\text { I believe the training received in university in the } \\
\text { specialisation in learning therapy was adequate. }\end{array}$ & 1 & 2 & 3 & 4 & 5 & 6 \\
\hline $\begin{array}{l}\text { My university training made me aware of the importance } \\
\text { of inclusion. }\end{array}$ & 1 & 2 & 3 & 4 & 5 & 6 \\
\hline \multicolumn{7}{|c|}{ If you are currently a teacher, what training was lacking for the appropriate attention to learning diversity? } \\
\hline \multicolumn{7}{|c|}{ After responding to the questionnaire, in what area did you receive the BEST training in university? } \\
\hline \multicolumn{7}{|c|}{ After responding to the questionnaire, in what area did you receive the WORST training in university? } \\
\hline
\end{tabular}




\section{References}

1. Arbilla, B. Recorrido por la Special Educationen el siglo XX. Desde Madrid a Pamplona, la contribución de Carmen Gayarre Galbete a la atención de personas con discapacidad intelectual. Príncipe De Viana 2011, 254, 533-549.

2. Ricoy, A.J. Formación docente y su relación con los contextos inclusivos. Rev. Int. De Apoyo A La InclusiónLogop. Soc. Y Multicult. 2018, 4, 160-171. [CrossRef]

3. García, C.; Lastikka, A.L.; Petreñas, C. Comunidades de aprendizaje. Scr. Nova Rev. Electrónica De Geogr. Y Cienc. Soc. 2013, 17, 27-43.

4. Ruíz, M.C.; Mérida, R. El desarrollo profesional docente derivado de la aplicación de los Proyectos de Trabajo en un aula infantil. Un estudio de caso. Rev. Complut. De Educ. 2016, 27, 477-497.

5. Salas, M.R. Reflexiones en torno a los maestros de Learning Therapy. J. Parents Teach. 2016, 365, 6-11.

6. World Health Organisation and the World Bank. Informe Sobre la Discapacidad. 2011. Available online: www.who.int/disabilities/world_report/2011/report.pdf (accessed on 1 June 2020).

7. Madrid-Vivar, D.; Mayorga-Fernández, M.J.; Del Río-Fernández, J.L. Proyecto interdisciplinar de innovación para la formación inicial del maestro en Educación Infantil. Ens. Rev. De La Fac. De Educ. De Albacete 2013, $28,107-131$.

8. García, R.; Gonzálvez, V.; Vázquez, V.; Escámez, J. Repensando la Educación: Cuestiones y Debates Para el Siglo XXI; Editorial Brief: Valencia, Spain, 2010.

9. Repáraz, C.; Arbúes, E.; Naval, C.; Ugarte, C. El índice cívico de los universitarios. Sus conocimientos, actitudes y habilidades de participación social. Rev. Española De Pedagog. 2015, 73, $23-52$.

10. Moriña, A.; Carballo, R. The impact of a faculty training program on inclusive education and disability. Eval. Program. Plan. 2017, 65, 77-83. [CrossRef] [PubMed]

11. United Nations. Human Rights. Convención Sobre Los Derechos de Las Personas Con Discapacidad. Available online: http://www.un.org/esa/socdev/enable/documents/tccconvs.pdf (accessed on 13 December 2006).

12. González-Gil, F.; Martín, E. Educación para todos: Formación docente, género y atención a la diversidad. Cuest. De Género De La Igual. Y La Difer. 2014, 9, 11-28. [CrossRef]

13. Vela, E.; Martín, L.; Martí, I. Analysis of ASD Classrooms: Specialised Open Classrooms in the Community of Madrid. Sustainability 2020, 12, 7342. [CrossRef]

14. Liesa, M.; Guillén, A.; Latorre, C.; Vázquez, S. La formación inicial de los graduados de magisterio en la atención al alumnado con altas capacidades: Retos y oportunidades para la educación inclusiva. Rev. De Currículum Y Form. Del Profr. 2019, 23, 46-66. [CrossRef]

15. Azorín, C.M. Análisis de instrumentos sobre educación inclusiva y atención a la diversidad. Rev. Complut. De Educ. 2017, 28, 1043-1060. [CrossRef]

16. Álvarez, J.L.; Buenestado, M. Predictores de las actitudes hacia la inclusión de alumnado con necesidades educativas especiales en futuros profesionales de la educación. Rev. Complut. De Educ. 2015, 26, 627-645.

17. González-Gil, F.; Martín-Pastor, E.; Orgaz, B. ¿Están los futuros profesores formados en inclusión?. Validación de un cuestionario de evaluación. Aula Abierta 2017, 46, 33-40. [CrossRef]

18. López-Torrijo, M.; Mengual-Andrés, S. An attack on inclusive education in secondary education. Limitations in initial teacher training in Spain. New Approaches Educ. Res. 2015, 4, 9-17. [CrossRef]

19. Loraine, M. Beginning teachers and inclusive education: Frustrations dilemmas and growth. Int. J. Incl. Educ. 2015, 20, 383-396.

20. Sharma, U.; Jacobs, D.T. Predicting in-service educators' intentions to teach in inclusive classrooms in India and Australia. Teach. Teach. Educ. 2016, 55, 13-23. [CrossRef]

21. Garrison-Wade, D.F. Listening to Their Voices: Factors that Inhibit or Enhance Postsecondary Outcomes for Students' with Disabilities. Int. J. Spec. Educ. 2012, 27, 113-125.

22. Moswela, E.; Mukhopadhyay, S. Asking for too much? The voices of students with disabilities in Botswana. Disabil. Soc. 2011, 26, 307-319. [CrossRef]

23. Stein, K.F. Experiences of College Students with Psychological Disabilities: The Impact of Perceptions of Faculty Characteristics on Academic Achievement. Int. J. Teach. Learn. High. Educ. 2014, 26, 55-65.

24. Strnadová, I.; Hájková, V.; Květoňová, L. Voices of university students with disabilities: Inclusive education on the tertiary level-A reality or a distant dream? Int. J. Incl. Educ. 2015, 19, 1080-1109. [CrossRef] 
25. Florian, L.; Linklater, H. Preparing teachers for inclusive education: Using inclusive pedagogy to enhance teaching and learning for all. Camb. J. Educ. 2010, 40, 369-386. [CrossRef]

26. Thomas, J.; Nelson, J. Métodos de Investigación en Actividad Física; Editorial Paidotribo: Barcelona, Spain, 2007.

27. Skjong, R.; Wentworth, B. Expert Judgement and risk perception. In Proceedings of the Eleventh International Offsore and Polar Engineering Conference, Stavanger, Norway, 17-22 June 2001; Available online: http: //research.dnv.com/skj/Papers/SkjWen.pdf (accessed on 15 January 2006).

28. Georg, D.; Mallery, P. SPSS for Windows Step by Step: A Simple Guide and Reference. 11.0 Update, 4th ed.; Allyn \& Bacon: Boston, MA, USA, 2003.

29. Bruschi, B.; Ranieri, M. University education: Quality, effectiveness, teacher training. Form@ re-Open J. Form. Rete 2018, 18, 1-6.

30. Martínez, M. Formación inicial de maestros. Bordon. Rev. De Pedagog. 2016, 68, 9-16. [CrossRef]

31. Montes, D.A.; Suárez, C.I. La formación docente universitaria: Claves formativas de universidades españolas. Rev. Electrónica De Investig. Educ. 2016, 18, 51-64.

32. Salazar-Gómez, E.; Tobón, S. Análisis documental del proceso de formación docente acorde con la sociedad del conocimiento. Rev. Espac. 2018, 39. Available online: http://www.revistaespacios.com/cited2017/ cited2017-17.html (accessed on 1 May 2020).

33. Romero, C. Argumentos sobre la formación inicial de los docentes en educación física. Profr. Rev. De Currículum Y Form. Del Profr. 2004, 8, 1-20.

34. Carbajo, C. El Perfil Profesional del Docente de Música de Educación Primaria: Autopercepción de Competencias Profesionales y la Práctica en el Aula. Ph.D. Thesis, Universidad de Murcia, Murcia, Spain, 2009.

35. Martínez, J.D. Perfil profesional idóneo del profesor de lengua extranjera: Creencias del profesorado en formación. Rev. Latinoam. De Estud. Educ. 2011, 41, 103-124.

36. Ortega, E.; Jiménez, J.M.; Palao, J.M.; Sainz, P. Diseño y validación de un cuestionario para valorar las preferencias y satisfacciones en jóvenes jugadoras de baloncesto. Cuad. De Psicol. Del Deporte 2008, 8, 39-58.

37. Wiersma, L.D. Conceptualization and development of the sources of enjoyment in youth sport questionnaire. Meas. Phys. Educ. Exerc. Sci. 2001, 5, 153-177. [CrossRef]

38. Zhu, W.; Ennis, C.D.; Chen, A. Many-faceted Rasch modelling expert judgment in test development. Meas. Phys. Educ. Exerc. Sci. 1998, 2, 21-39. [CrossRef]

Publisher's Note: MDPI stays neutral with regard to jurisdictional claims in published maps and institutional affiliations.

(C) 2020 by the authors. Licensee MDPI, Basel, Switzerland. This article is an open access article distributed under the terms and conditions of the Creative Commons Attribution (CC BY) license (http://creativecommons.org/licenses/by/4.0/). 